\title{
Herbivory and plant competition reduce mountain beech seedling growth and establishment in New Zealand
}

\author{
Sean W. Husheer ${ }^{1,4, *}$, Alastair W. Robertson ${ }^{1}$, David A. Coomes ${ }^{2}$ and Chris M. Frampton ${ }^{3}$ \\ ${ }^{1}$ Ecology Group, Institute of Natural Resources, Massey University, Private Bag 11222, Palmerston North, \\ New Zealand; ${ }^{2}$ Department of Plant Sciences, University of Cambridge, Downing Street, Cambridge, CB2 \\ $3 E A$, United Kingdom; ${ }^{3}$ Christchurch School of Medicine and Health Sciences, Christchurch, New Zealand; \\ ${ }^{4}$ New Zealand Forest Surveys, 15 McElwee Street, Jervoistown, Napier, New Zealand; *Author for \\ correspondence (e-mail: shusheer@clear.net.nz)
}

Received 14 April 2004; accepted in revised form 15 July 2005

Key words: Clipping, Deer, Natural and simulated herbivory, Nothofagus solandri var. cliffortioides

\begin{abstract}
The effect of herbivory and resource availability on the competitive ability of different plant species has been an area of intense debate amongst plant ecologists for at least two decades, but the interactive effects of herbivory and plant competition between woody and herbaceous plants are rarely studied and theory is poorly developed. This study used experimental manipulations on transplanted and naturally occurring mountain beech (Nothofagus solandri var. cliffortioides) seedlings to show the effects of deer browsing and competition from deer-induced, herbaceous turf communities on mountain beech regeneration in New Zealand. Differences in the species composition of these turfs had little effect on mountain beech seedling establishment, but turf removal increased seedling growth and survivorship, showing that competition with other plants had direct effects on mountain beech regeneration. Deer browsing reduced the establishment and growth of seedlings, but the size of this effect did not vary with light and nutrient availability. There was no immediate compositional response of turf communities following the removal of deer browsing. The addition of nutrients appeared to reduce the intensity of belowground competition (stem growth increased relative to root growth) and increase seedling mortality, but there was no effect of changing levels of light. These results showed simple and direct negative effects of deer browsing on mountain beech regeneration. Indirect negative effects on regeneration were caused by deer-induced turf communities. We found little evidence for interactive effects between herbivory, plant competition and the availability of light or nutrients on seedling regeneration, which suggests that these factors acted independently.
\end{abstract}

\section{Introduction}

Plant seedling demographics are strongly influenced by herbivory (Crawley 1983; Hulme 1996), inter-specific plant competition and resource availability (Goldberg and Barton 1992; Hjältén et al. 1993; Ryser 1993). Nevertheless, general rules on interactions between the influences of herbivory and competition on plants have not been successfully developed (Van de Koppel et al. 1996; Van der Wal et al. 2000), perhaps because interactive effects vary among habitats. Relationships between the effects of herbivory and resource availability are also unclear, despite extensive 
research on the effects of browsing, and light and nutrient levels. Some studies on the ability of seedlings to tolerate herbivory along gradients of resource availability conclude that individual plants in highly productive environments are best able to recover from herbivory (e.g. Coley 1983; McNaughton 1983; Coughenour et al. 1985; Maschinski and Whitham 1989; Louda et al.1990; Rosenthal and Kotenen 1994; Bazzaz 1996; Crawley 1997; Meyer 2000). Other studies demonstrate that seedlings better tolerate herbivory in lower productivity environments (e.g. Hilbert et al. 1981; McNaughton and Chapin 1985; Van Auken and Bush 1989; Schmid et al. 1990; Bonser and Reader 1995), or that resource availability is not important for seedling recovery (Wandera et al. 1992). The ability of plants to tolerate herbivory can also vary with plant species or functional group (Hicks and Reader 1995). For instance, in high resource environments, monocotyledonous species may be more competitive under intense grazing than dicotyledonous species because of differences in responses to herbivory (Hawkes and Sullivan 2001).

Studies that address the combined effects of competition and herbivory on plant communities along productivity gradients also provide conflicting conclusions (for reviews see: Swank and Oechel 1991; Belsky 1992; Goldberg and Barton 1992; Reader 1992; Cebrián and Duarte 1994; Gough and Grace 1998). Several studies have shown that plant communities are most resistant to herbivore-induced shifts in species composition in low productivity environments (Grime 1979; Van der Wal et al. 2000; Virtanen 2000; but see Van de Koppel et al. 1996) or that plant competition increases with increased herbivory (Huisman et al. 1999). Chase et al. (2000) conclude that the effects of herbivores in high productivity situations are reduced through increased species turnover.

Studies on the effects of herbivory on succession also provide conflicting conclusions. A review by Davidson (1993) concludes that grazing tends to accelerate compositional shifts from herbaceous towards woody plants. In contrast, Wiser et al. (1997) show that beech seedlings do not establish when dense turfs were present in the South Island of New Zealand. In Scandinavia and western Europe, grazing by native herbivores maintains semi-natural grasslands and grazing lawns (Eriksson et al. 1995; Hellström et al. 2003; Olff et al. 1999). Reductions in woody seedling density have also been observed in New Zealand forests following the introduction of a suite of mammalian herbivores in the 19th and 20th centuries. New Zealand forests evolved with invertebrate and recently-extinct avian herbivores, and in contrast to plants in most other parts of the world many plant species are poorly adapted to the browsing strategies of mammalian herbivores (Greenwood and Atkinson 1977; Bond et al. 2004). In the central North Island of New Zealand, intense browsing by introduced sika deer (Cervus nippon) appears to have induced shifts in ground cover composition towards browse-tolerant, turf-forming communities of herbs, bryophytes and ferns (Husheer et al. 2003), as well as suppressed mountain beech (Nothofagus solandri var. cliffortioides) forest regeneration through direct browsing on seedlings (Husheer and Robertson 2005). Deerinduced turf communities may also prevent mountain beech canopy regeneration through competitive exclusion of seedlings. The relationships between herbivory, browse-tolerance and resource availability need to be better understood to develop general rules in a variety of habitats including mountain beech forest (Di Tommaso and Aarssen 1989; Louda et al. 1990; Taylor et al. 1997; Husheer and Robertson In Press).

This study examined responses of woody seedlings to herbivory and competition from herbaceous plants, along gradients of resource availability, and to differentiate between the direct and indirect impacts of herbivores. Interactive effects of herbivory and plant competition could be: (1) positive, with increased herbivory resulting in increased plant competitive effects on woody seedlings from browse-tolerant herbaceous plants, thereby reducing woody seedling growth and survivorship; (2) negative, with increased herbivory reducing plant competitive effects on woody plants; or (3) simply additive, with no evidence of interactive effects of plant competition and herbivory on seedling demographics. We aimed to determine the relative importance of competition from turf communities and deer herbivory to mountain beech seedlings along natural and experimental gradients of nutrient and light availability. 


\section{Methods}

Our study area in the Kaimanawa Ecological Region (MacEwen 1987) centres on a series of ranges running north-east to south-west in the central North Island $\left(39^{\circ} \mathrm{S}, 176^{\circ} \mathrm{E}\right)$ of New Zealand. Geology is predominantly Jurassic folded sandstone, with soils derived from a combination of the bedrock or ash and ignimbrite flows from volcanic eruptions (Wilson et al. 1993). Forests are dominated by red (Nothofagus fusca) and silver beech (Nothofagus menziesii) below $1000 \mathrm{~m}$ altitude, but above this mountain beech dominates to the treeline at 1400-1500 m a.s.l. Tree and shrub diversity in the understorey is low compared to lower altitude New Zealand forests, and commonly consists of Coprosma pseudocuneata, Coprosma "taylorae", Griselinia littoralis and Phyllocladus alpinus. Groundcover is more diverse, and dense herbaceous turf and bryophyte communities often occur at sites of canopy tree death. Turf communities such as these form dense grazing lawns that are both maintained by and attractive to herbivores (McNaughton 1984; Posse et al. 2000) and typically include bryophytes (e.g. Bryum billiardierei, Dicranoloma robustum, Dendroligotrichum dendroides, Ptychomnion aciculare), herbs (e.g. Acaena anserinifolia, Hydrocotyle moschata, Lagenophora strangulata and Nertera dichondrifolia), and grasses or sedges (e.g. Poa breviglumis, Rytidosperma gracile, Microlaena avenacea, Uncinia filiformis). All of these plants can have prostrate growth forms or develop dense, lowstature swaths that can reduce vulnerability to herbivory.

Between September 1998 and March 1999, 12 sites within our Kaimanawa study area were located in mountain beech dominant forest with low basal area $\left(<30 \mathrm{~m}^{2} \mathrm{ha}^{-1}\right)$, at altitudes $(1300-$ $1430 \mathrm{~m}$ ) near treeline. Basal area was assessed at each site by measuring all trees $>3 \mathrm{~cm}$ diameter at breast height $(1.35 \mathrm{~cm})$ in $20 \mathrm{~m} \times 20 \mathrm{~m}$ plots. The mean distance separating sites was $1.8 \mathrm{~km}$. Two plots $(10 \mathrm{~m} \times 10 \mathrm{~m})$ were established at each site, and one of the pair was fenced to exclude deer. To test whether deer were able to prevent mountain beech from regenerating indirectly by maintaining competitive turf communities, or directly through browsing on mountain beech seedlings, the responses of naturally occurring seedlings to the removal of herbivory were monitored at seven of these sites where $>10$ mountain beech seedlings were present. Eight of these 12 sites had dense turf communities ( $>50 \%$ turf cover) and mountain beech seedlings were transplanted within deer exclosure fences at these sites and monitored for two years. Factorial treatments of shading, nutrient addition, turf removal and herbivory were applied to seedlings to test the hypothesis that the intensity of interactions between woody and herbaceous plant competition increased with herbivory and increasing levels of resource availability. At 3 of the 12 sites, both transplanted and naturally occurring seedlings were monitored within fenced plots, and at these sites seedlings were transplanted $>1 \mathrm{~m}$ from the $10 \mathrm{~m} \times 10 \mathrm{~m}$ natural seedling plots.

\section{Exclusion of deer from naturally occurring seedlings}

Naturally occurring mountain beech seedlings were monitored for 3 years in paired fenced and unfenced plots to determine the demographic responses of mountain beech seedlings to the removal of herbivory along natural gradients of resource availability and plant competition. Each $10 \mathrm{~m} \times 10 \mathrm{~m}$ seedling plot was divided into 16 $2.5 \mathrm{~m} \times 2.5 \mathrm{~m}$ sub-plots. In each sub-plot the heights of all established mountain beech seedlings $(5-135 \mathrm{~cm}$ high) were monitored for 3 years after initially being measured during the austral summer of 1998/1999 in paired-plots at seven sites. A numbered aluminium tag was attached to each seedling's stem and its pull-up height was measured (in $\mathrm{cm}$ to the end of the previous season's growth) following Husheer (2003). In the austral summer of 2001/2002 all living seedlings were relocated and their heights remeasured. Any new seedlings that had reached the $5 \mathrm{~cm}$ size class since the 1998/1999 survey were also measured so that recruitment could be calculated.

To determine whether the removal of ungulate herbivory through fencing would induce compositional changes in turf and shrub communities, all species of vascular plants, bryophytes and lichens growing in mineral soil were identified and estimates of cover were made for each sub-plot, in two tiers $(<15 \mathrm{~cm} ; 15-135 \mathrm{~cm})$, using a six-point 
inverse $\log$ scale $(1=<2 \%$ cover, $2=2-5 \%$, $3=6-25 \%, \quad 4=26-50 \%, \quad 5=51-75 \%, \quad 6=76-$ 100\%; Mueller-Dombois and Ellenberg 1974) in 2002. Lichens and bryophytes were not identified when they had cover $<2 \%$. Bare ground with no plant cover was estimated using the same scale. Slope was measured at each sub-plot to the nearest $5^{\circ}$ using an inclinometer, and aspect was measured to the nearest $5^{\circ}$ using a compass. For analysis, aspect was converted to degrees from true north. Soil samples $(200-250 \mathrm{ml})$ were taken from each sub-plot and were transported to a glasshouse for bioassay based on the method of Lee and Fenner (1989). Agrostis tenuis seed (0.7 g) was sown in these soil samples, harvested after four months and dried at $90{ }^{\circ} \mathrm{C}$ until weight stabilised. The leaf dry weight was measured to the nearest $\mathrm{mg}$, and this weight was used as an index of soil productivity. A black and white hemispherical photograph was taken at $135 \mathrm{~cm}$ above the centre of each sub-plot using a Nikon 990 digital camera and hemispherical lens. This image was used to calculate the percentage of transmitted light available at each sub-plot using GLA 2 software (Frazer et al. 1999). Images captured with digital cameras under dense canopies and broken skies can produce variable results, but digital images captured under relatively open canopies and overcast skies (such as in this study) are generally more reliable (Frazer et al. 2001).

\section{Transplanted seedling experiment}

A factorial combination of treatments were applied to transplanted seedlings for 2 years to determine the effects of light and nutrient availability, competition from other plants, and herbivory on mountain beech seedling growth and mortality. At each of eight sites, five mountain beech seedlings $(4.0-30.6 \mathrm{~cm}$ high) were planted within $1620-\mathrm{cm}$ radius $\left(0.126 \mathrm{~m}^{2}\right)$ replicate subsub-plots (cells), following a conventional factorial split-plot design (Sokal and Rohlf 1995). These 16 cells were systematically located on ground with $<25 \%$ cover of woody plant species $(5-135 \mathrm{~cm})$ and were centred $>1 \mathrm{~m}$ apart within deer-proof fences. At each site, a sub-plot treatment of shading was provided to one group of eight cells by a shade tunnel designed to remove $80 \%$ of available light. The tunnel was constructed of steel rod, with shade cloth wired to this structure at $1 \mathrm{~m}$ intervals. A Li-cor L250 light meter confirmed that $83.7 \%(\mathrm{SE}=0.34 \%)$ of light was blocked by shade cloth.

Nutrient addition, turf removal and simulated herbivory treatments were applied in a $2 \times 2 \times 2$ randomised, complete factorial design to cells both within the shade tunnel and to adjacent unshaded cells. This means that each treatment was applied to 8 of all 16 cells at each site, and all possible combinations of treatments occurred at each site. Fifty grams of slow-release fertiliser (Osmocote 12 month; $15 \% \mathrm{~N}, 3 \% \mathrm{P}, 9.1 \% \mathrm{~K}, 1.2 \% \mathrm{Mg}$ ) was applied over randomly selected $0.126 \mathrm{~m}^{2}$ cells at the time of establishment. This level of nutrient addition provided $60 \mathrm{~g}$ of $\mathrm{N} \mathrm{m}^{-2}$ and is consistent with other studies (e.g. Cahill 1999, $2.8 \mathrm{~g}$ of $\mathrm{N} \mathrm{m}^{-2}$; Nams, Folkard and Smith 1996, $18.8 \mathrm{~g}$, $25 \mathrm{~g}^{2}$ and $125 \mathrm{~g} \mathrm{~N} \mathrm{~m}^{-2}$ year $^{-1}$; Wilson and Tilman 1991, $5.4 \mathrm{~g}, 17.0 \mathrm{~g}$ of $\mathrm{N} \mathrm{m}^{-2}$ year $^{-1}$; Coomes and Grubb 1998, 1.4 and $3.2 \mathrm{~g} \mathrm{~N} \mathrm{~m}^{-2}$ ). Cells selected for turf removal had all bryophytes, herbs and woody seedlings removed prior to planting of seedlings, and at 6 month intervals thereafter. On seedlings selected for herbivory, all stems and branches $>1.5 \mathrm{~mm}$ diameter were clipped with scissors and removed in winter 2001 to simulate browsing by deer. This reduced clipped seedlings in height by a mean $( \pm \mathrm{SD})$ of $30.0 \pm 6.3 \%$.

The cover of vascular plants, bryophytes and lichens growing in soil was estimated for each cell without turf removal using a six-point scale (Mueller-Dombois and Ellenberg 1974). Transplanted seedling heights were measured immediately after planting in 2000 (from root-stem intersection to apical bud), again when simulated herbivory was applied in 2001, and once more immediately prior to being uprooted and removed for weighting of roots, stems and leaves in the winter of 2002. Roots and stems were sorted prior to drying at $90^{\circ}$ to a stable weight and weighed to the nearest $\mathrm{mg}$.

\section{Data analysis}

To determine the demographic consequences of the removal of browsing on naturally occurring mountain beech seedlings we calculated for each 
$10 \mathrm{~m} \times 10 \mathrm{~m}$ plot, (1) annual recruitment and (2) mortality rates (McCune and Cottam 1985); (3) mean relative growth rates (RGR); and (4) the percentage of established seedlings surviving from 5 to $135 \mathrm{~cm}$.

Recruitment $=\left(1+\mathrm{B}_{x}\right)^{1 / 3}-1$, where

$B_{x}=$ proportion of new seedlings for 3 years

Mortality $=1-\left(1-\mathrm{Q}_{x}\right)^{1 / 3}$, where

$Q_{x}=$ proportion of dead seedlings for 3 years

$$
\begin{aligned}
& \mathrm{RGR}=\left(\log _{\mathrm{e}} \text { seedling height } 2001\right. \\
& \left.\quad-\log _{\mathrm{e}} \text { seedling height } 1998\right) / 3 \text { years }
\end{aligned}
$$

Survivorship from 5 to $135 \mathrm{~cm}(\%)$

$$
\begin{aligned}
= & \left(- \text { mortality }\left(\log _{\mathrm{e}} 135 \mathrm{~cm} / 5 \mathrm{~cm}\right) / \mathrm{RGR}\right) \\
& \times 100 \times \exp
\end{aligned}
$$

Paired $t$-tests were used to test for differences in seedling recruitment, mortality, growth and survival between fenced and unfenced plots. When no difference was detected (at type I $p>0.05$ ), power analysis was employed to determine the probability of not detecting a $100 \%$ mean difference in these parameters between paired fenced and unfenced plots if this difference actually had existed (type II $p$ ). Vegetation composition $(<15 \mathrm{~cm}$ height tier) was summarised for each $2.5 \mathrm{~m} \times 2.5 \mathrm{~m}$ sub-plot and plot using Detrended Correspondence Analysis (DCA) in CANOCO 4.0 (Ter Braak and Smilauer 1998). Environmental characteristics were summarised in SYSTAT (SPSS 2000) for each $10 \times 10 \mathrm{~m}^{2}$ plot before statistical analysis was undertaken using General Linear Models. The numbers of small seedlings $\left(<5 \mathrm{~cm}\right.$ high) counted in each plot were $\log _{\mathrm{e}}$ transformed to meet assumptions of ANOVA. Means are presented \pm standard errors.

For the transplant experiment, the relationship between individual transplanted seedling root and stem biomass was calculated using linear regression forced through the origin. Residual values were then used as an index of stem-root weights. This approach limits scaling error inherent in alternative ratio based indices (Atchley et al. 1976). Mean transplanted seedling heights, mean stem-root index and the mean number of seedlings with living leaf material remaining in each replicate plot in 2002 were calculated before the effect of experimental manipulations on means were tested with a split-plot ANCOVA in SYSTAT (SPSS 2000), using sites as a blocking variable. Transplanted seedling heights in the year 2000 were used as a covariate and means adjusted accordingly in ANCOVA to produce least square (L.S.) means (Sokal and Rohlf 1995). By using L.S. means for each treatment the effects of other treatments are allowed for. Means and unadjusted means are presented \pm standard errors in results unless otherwise stated.

Constrained ordination methods were used in CANOCO 4.0 (Ter Braak and Smilauer 1998) to determine the effect of the experimental manipulations on turf community species composition. For the natural seedling experiment, sites were treated as blocks in a randomised block Canonical Correspondence Analysis (CCA) to reduce unexplained variation among sites. An automatic forward selection procedure was used to test for the effect of deer exclusion fencing, total transmitted light, soil productivity and slope on species composition (calculated from $<15 \mathrm{~cm}$ height mean sub-plot cover data) in 2001/2002 in each plot. For the transplanted seedling experiment, we used a split-plot, partially constrained CCA to detect differences in $<5 \mathrm{~cm}$ high tier species composition in 2002 within $20 \mathrm{~cm}$ radius, where turfs had not been removed. A randomised, forward-stepwise procedure was used to test for the significance of shading as a main-plot effect. A separate stepwise procedure was then used to test for the split-plot effects in cells of herbivory, turf removal and nutrient addition and their interactions. Baseline species composition was allowed for by using DCA of 2000 composition to calculate axis 1, 2, 3 and 4 scores and using these as constraining covariates in the CCA. Sites were also treated as blocking covariates in analysis.

\section{Results}

Effects of deer exclusion on naturally occurring seedlings

When fences were established and the initial baseline measurements of seedling heights taken in 
Table 1. Summary of baseline (means $\pm \mathrm{SD}$ ) and post-experimental measurements (means $\pm \mathrm{SE}$ ) for the natural seedling experiment.

\begin{tabular}{lcc}
\hline Parameter & Fenced plots & Unfenced plots \\
\hline Baseline seedling measurement (1998) & & \\
$\quad$ Proportion browsed & $0.97 \pm 0.04$ & $0.97 \pm 0.04$ \\
$\quad$ Seedling counts & $64.6 \pm 57.7$ & $73.1 \pm 103.0$ \\
Final measurement (2002) & $0.19 \pm 0.03$ & $0.08 \pm 0.03$ \\
Mean relative growth 5-135 cm & $6.8 \pm 2.6$ & $5.6 \pm 1.7$ \\
Mean annual mortality 5-135 cm (\%) & $31.3 \pm 12.1$ & $20.1 \pm 16.2$ \\
Mean of seedlings surviving to 135 cm (\%) & $11.2 \pm 4.4$ & $10.8 \pm 4.4$ \\
Mean annual recruitment $>5 \mathrm{~cm}(\%)$ & & $124.7 \pm 42.4$ \\
Environmental parameters (2002) & $126.8 \pm 48.9$ & $26.1 \pm 10.8$ \\
Aspect (mean ${ }^{\circ}$ from true north) & $23.5 \pm 10.9$ & $59.1 \pm 15.5$ \\
Slope ( ${ }^{\circ}$ & $52.0 \pm 15.4$ & $0.9 \pm 0.4$ \\
Total transmitted light (mean\%) & $1.1 \pm 1.0$ & $1.2 \pm 0.2$ \\
Bare ground (mean 0-6) & $1.3 \pm 0.2$ & $2.5 \pm 0.8$ \\
Soil productivity (mean g) & $2.4 \pm 0.8$ & \\
Mean axis 1 DCA Scores & & \\
\hline
\end{tabular}

Baseline measurements are the mean proportion of seedlings $(5-135 \mathrm{~cm})$ browsed and mean numbers of seedlings counted in $10 \mathrm{~m} \times 10 \mathrm{~m}$ plots in four height classes upon plot establishment and fencing in 1998/99. Mean plot aspect, slope, total transmitted light, bare ground cover, soil productivity and DCA axis 1 scores were estimated from sampling in 2002. Final measurements are the effects of fencing on mean seedling relative growth rates, mortality, recruitment and survivorship from 1998 to 2002.

$10 \mathrm{~m} \times 10 \mathrm{~m}$ plots in 1998 , nearly all mountain beech seedlings present had been browsed in both fenced and unfenced plots (97\%; Table 1). Initial counts of mountain beech seedlings were also similar between fenced and unfenced plots, although the high standard deviations indicate considerable density variation among plots. We also summarised the comparability of fenced and unfenced plots for key environmental characteristics measured in 2001/02 and found that paired plots had similar means for aspect, slope, total transmitted light, indices of plant cover in the ground cover tier $(<5 \mathrm{~cm})$, bare-ground cover, understorey composition (axis 1 DCA scores) and soil productivity (Table 1).

Mountain beech seedlings continued to be browsed and their growth retarded by deer between 1998 and 2002. In unfenced plots, 408 browsed seedlings $(5-135 \mathrm{~cm})$ had significantly lower relative growth rates than the 23 seedlings that showed no signs of browsing (mean browsed $\mathrm{RGR}=0.01 \pm 0.01$ vs. mean unbrowsed RGR $=0.05 \pm 0.02 ; F_{1,424}=7.582, p=0.006$ ), suggesting that deer browsing was capable of inhibiting seedling growth. Furthermore, established seedlings $(5-135 \mathrm{~cm})$ that were not exposed to deer browsing after being protected by fences in 1998 had higher mean relative growth rates than seedlings in unfenced plots (paired $t_{5}=3.14$. $p=0.026$;
Table 1). However, there was no significant difference in mortality $\left(t_{6}=0.49, p=0.643\right.$, Type II $p=0.541)$, recruitment $\left(t_{6}=0.28, p=0.786\right.$, Type II $p<0.001)$ or survivorship of established seedlings $\left(t_{5}=0.87, p=0.423\right.$, Type II $\left.p=0.760\right)$ between fenced and unfenced plots.

The natural seedling experiment showed that deer browsing had also inhibited the establishment of small seedlings ( $<5 \mathrm{~cm}$ high). In 2001, there were significantly more small seedlings in fenced plots compared to unfenced plots (fenced LS mean $=196.0 \pm 111.0$ seedlings plot $^{-1}$; unfenced $=$ $16.9 \pm 10.0$ seedlings plot $^{-1} ;$ paired $t_{6}=3.18$, $p=0.019$ ).

Variance decomposition of ANOVA on small seedling abundance between the seven fenced plots showed that there was considerable variation in seedling counts among the $10 \mathrm{~m} \times 10 \mathrm{~m}$ plots (variance $=1.7 ; \min =8, \max =348$ ) as well among the $2.5 \mathrm{~m} \times 2.5 \mathrm{~m}$ sub-plots (variance $=0.87$, $\min =0, \max =146$ ). Therefore, we attempted to investigate in more detail the factors responsible for variation in small seedling counts $(<5 \mathrm{~cm})$ at the plot and sub-plot scale. At the plot level, there was no significant effect on small seedling counts of mean total transmitted light, mean soil productivity index $(\mathrm{g})$, mean sub-plot slope $\left(^{\circ}\right)$, mean bare-ground score $(1-6)$ or ground cover plant composition (mean axis 1 DCA) as shown by a 
multiple regression $(p>0.067)$. At the sub-plot level, a randomised block ANOVA showed no significant effect of these same variables on seedling counts $(\mathrm{df}=6,98 ; p>0.224)$. Thus, we were unable to explain any of the patterns in variance of small seedling counts using environmental parameters. A randomised block CCA showed that ground cover species composition also did not significantly vary with the exclusion of deer $(\gamma=0.08, F=0.52, p=0.865)$, or with mean soil productivity $(\gamma=0.19, F=1.29, p=0.225)$, total transmitted light $(\gamma=0.13, F=0.93, p=0.510)$ or plot slope $(\gamma=0.11, F=0.71, p=0.715)$.

\section{Effects of turf removal, clipping, nutrient addition} and shading on transplanted seedlings

Following the removal of turf vegetation in 1998, transplanted seedlings had significantly taller stems by 2002 compared to seedlings with no turf removal (Figure 1; Table 2). Clipped seedlings were significantly shorter in 2002 than unclipped seedlings. There were no significant effects of shading or nutrient addition on stem heights in 2002, nor were there any significant interactions between shading, nutrient addition, turf removal or clipping on stem heights.

Seedlings in plots with nutrient addition had three times higher L.S. mean stem-root index values than seedlings in plots with no nutrient addition (Figure 1; Table 2), showing that increased nutrient availability significantly increased stem weight relative to root weight. Clipping and turf removal treatments had the opposite effect to nutrient addition. Clipped seedlings had nearly five times lower L.S. mean stem-root index values compared to seedlings that had not been clipped and seedlings with turf removal had nearly three times lower L.S. mean stem-root index than seedlings without turf removal. This effect may be partly due to incomplete recovery of roots from seedlings in the uncleared plots (Cahill 2002). There were no
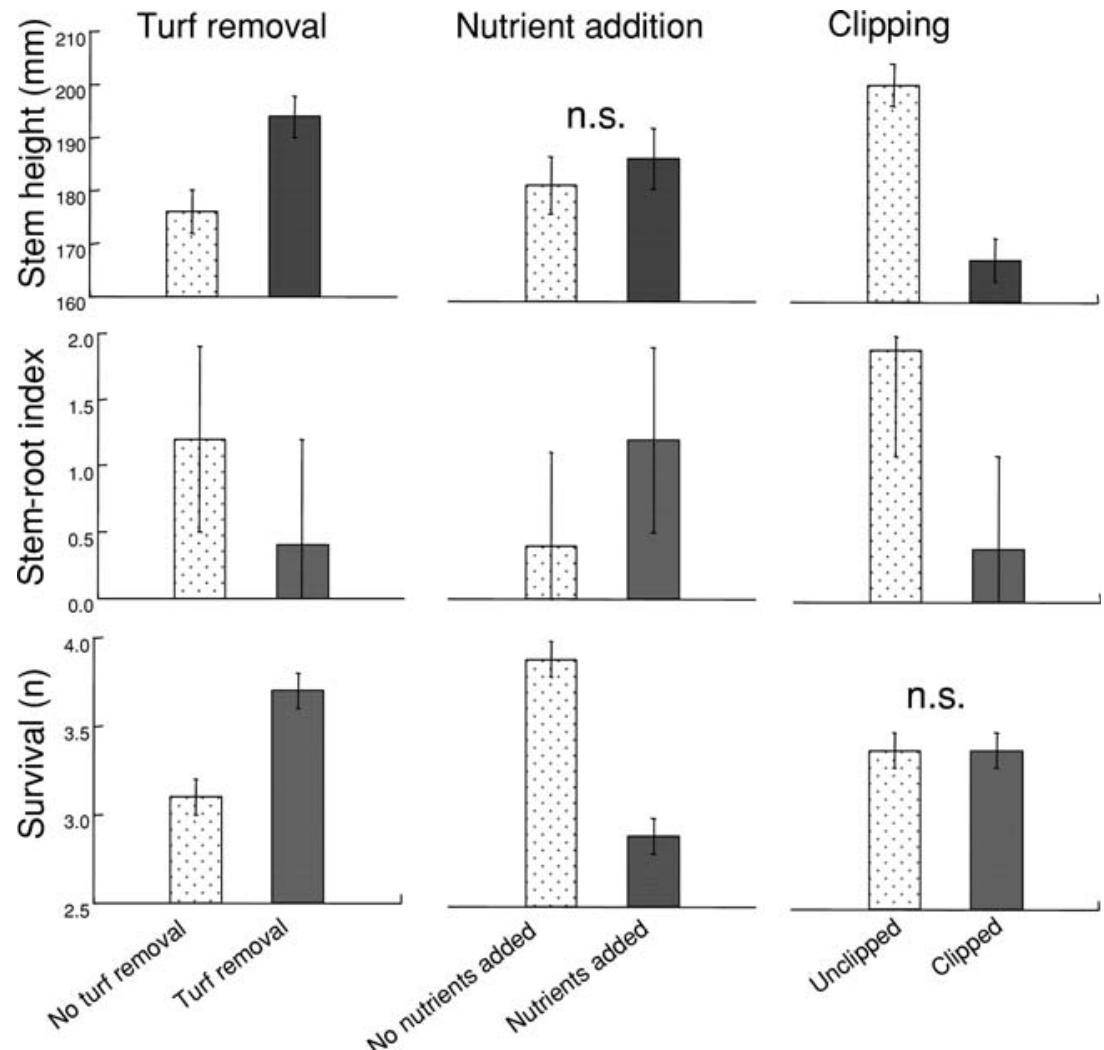

Figure 1. Least square means $( \pm \mathrm{SE})$ of transplanted seedling heights, stem-root indices and survival for treatments of turf removal, nutrient addition and clipping (n.s. $=$ not significant at $p \geq 0.05$ ). 
Table 2. Transplanted seedling split-plot ANOVA of the of treatments of shading, nutrient addition, turf removal, and simulated herbivory on mean seedling height $(\mathrm{mm})$ in 2002, mean stem-root index and mean number of live seedlings remaining in each plot.

\begin{tabular}{|c|c|c|c|c|c|c|c|c|c|c|c|c|}
\hline & \multicolumn{4}{|c|}{ Height 2002} & \multicolumn{4}{|c|}{ Stem-root index } & \multicolumn{4}{|c|}{ Survival } \\
\hline & df & Mean-square & $F$ & $p$ & df & Mean-square & $F$ & $p$ & $\mathrm{df}$ & Mean-square & $F$ & $p$ \\
\hline \multicolumn{13}{|l|}{ Main plot } \\
\hline Shade & 1 & 1269 & 0.128 & 0.731 & 1 & 0.016 & 1.615 & 0.244 & 1 & 7.508 & 1.538 & 0.255 \\
\hline Blocks & 7 & 12816 & 14.018 & $<0.001$ & 7 & 0.009 & 1.819 & 0.094 & 7 & 21.660 & 15.197 & $<0.001$ \\
\hline Main plot error & 7 & 9876 & & & 7 & 0.010 & & & 7 & 4.883 & & \\
\hline \multicolumn{13}{|l|}{ Split plot } \\
\hline Nutrient addition & 1 & 1326 & 1.450 & 0.231 & 1 & 0.024 & 4.735 & 0.032 & 1 & 31.008 & 21.755 & $<0.001$ \\
\hline Turf removal & 1 & 9391 & 10.272 & 0.002 & 1 & 0.045 & 8.896 & 0.004 & 1 & 14.445 & 10.135 & 0.002 \\
\hline Simulated herbivory & 1 & 34254 & 37.466 & $<0.001$ & 1 & 0.033 & 6.419 & 0.013 & 1 & 0.008 & 0.005 & 0.941 \\
\hline Interactions & 6 & 1100 & 1.203 & 0.312 & 6 & 0.009 & 1.867 & 0.096 & 6 & 0.852 & 0.598 & 0.731 \\
\hline Mean seedling height 2000 & 1 & 75042 & 82.081 & $<0.001$ & 1 & 0.031 & 6.099 & 0.015 & & & & \\
\hline Split plot error & 94 & 914 & & & 86 & 0.005 & & & 103 & 1.425 & & \\
\hline
\end{tabular}

Second-order interactions of treatments are included in one term. Seedling height $2000(\mathrm{~mm})$ is treated as a covariate for calculation of seedling height 2002 and stem-root index least square means.

significant interactions between shading, nutrient addition, turf removal, or simulated herbivory on stem-root index L.S. means.

Seedling survivorship was significantly higher when turfs were removed compared to seedlings without turf removal (Figure 1; Table 2). There was significantly lower seedling survival in replicate cells with nutrient addition compared to plots without nutrient addition. There were no significant differences in survivorship between seedlings in plots with clipping or shading, or second order treatment interactions.

Finally, there was no significant effect of shading on changes in $<5 \mathrm{~cm}$ tier species composition in replicate plots without turf removal $(\gamma=0.10$, $F=1.02, p=0.785)$. A separate stepwise procedure showed no significant effects on changes in species composition of mountain beech seedling clipping $(\gamma=0.07, F=0.97, p=0.130)$, nutrient addition $(\gamma=0.11, F=1.14, p=0.055)$ or second- and thirdorder interactions of shading, nutrient addition and clipping within split-plots $(p>0.420)$.

\section{Discussion}

It is widely accepted that selective herbivory is generally detrimental to plants (e.g. Darwin 1872; Pacala and Crawley 1992; but see Coley et al. 1985) and reduces the competitive ability of poorly defended species (Crawley 1993), which can shift community composition towards browse-tolerant or browse-resistant species (Louda et al. 1990; Crawley 1997; Collins et al. 1998). But, does herbivory affect competition between woody and herbaceous plants, and does this vary with light and nutrient availability?

In this study, natural and simulated deer herbivory directly reduced mountain beech seedling establishment and growth, and the presence of turf communities reduced seedling growth and survival (Table 1; Figure 1). There was no evidence that herbivory altered the competitive effects of turf communities on mountain beech seedlings. The effects of deer browsing did not vary with composition of competing plants, light availability or soil productivity for naturally occurring seedlings, and the effects of clipping did not vary with nutrient addition, shading, or turf removal for transplanted seedlings (Table 2). These results build upon models developed by Grover (1995) and Leibold (1996) that show herbivory alters the relative competitive advantage of different plant species. The results of our study are consistent with these models and also suggest that the effects of herbivory from introduced deer and competition between plants quickly increased, but did not interact, along gradients of productivity. Our results challenge theory developed by Grime (1979) and Whittaker (1979) who proposed strong interactions between herbivory and plant competition intensity.

Given the importance of understanding the effects of herbivory on competitive interactions 
between woody and herbaceous plants for forest dynamics, it is surprising that previous studies have not more fully tested these theories in forested systems. Previous studies in non-forest habitats reached contrasting conclusions, particularly for gramminoids, which suggests that the strength of interactions between plant competition and herbivory may vary between habitats. Although we find no evidence for interactive effects between the intensity of plant competition and herbivory along gradients of productivity in our study area during our three year study, this may not be the case for all habitats or over longer time periods. Swank and Oechel (1991) found strong interactive effects of herbivory, nutrient and water addition, and root trenching on plant survival and growth in North American chaparral. Cahill (1999) showed that in a Pennsylvanian grassland the interactive effects of above and below ground competition became multiplicative with nutrient addition. In contrast, Dormann et al. (2000) showed no increases in the intensity of herbivory with increasing biomass in a grass duneland in the Netherlands. In a review of studies that explored relationships between productivity and intensity of herbivory, Cebrián and Duarte (1994) concluded that the effects of herbivory on plants appeared to be independent of ecosystem productivity and were more closely linked to the growth rate of the plant species present. However, Virtanen (2000) expressed concern that Cebrián and Duarte (1994) did not consider studies of slow-growing plants in low-productivity, high-latitude sites, which showed considerable impacts of herbivores (Leader-Williams et al. 1987), although Kullberg and Welander (2003) found that water limitation did not significantly interact with simulated herbivory on beech seedlings in Sweden.

In the transplanted seedling experiment in this study, removal of competing herbs increased growth of mountain beech seedlings. Addition of nutrients increased stem growth relative to root growth, but not stem growth overall, and reduced seedling survival (Figure 1). These results suggest that competition for space but not nutrients limited stem growth and that more resources were spent on root mass growth when nutrients are limited. Increased stem growth relative to root growth with nutrient addition indicates that increasing nutrient availability shifted plant competition aboveground, where shading treatments showed no effect of light limitation. This is consistent with previous studies in situations of limited nutrient availability (Coomes and Grubb 2000), suggesting that mountain beech will develop the organ system for the resource that is in shortest supply (but see Platt et al. 2004). In our study it is possible that an increase in aboveground competition may have been responsible for increased beech seedling mortality following the addition of nutrients.

None of the apparent changes in competitive ability in mountain beech varied with simulated herbivory, which was also found by Wandera et al. (1992) for shrubs. Thus, no evidence from our study suggests that the tolerance of mountain beech seedlings to herbivory varies with resource availability. Other studies have provided evidence that the tolerance of plants to herbivory can vary along gradients of productivity. In a review, Bryant et al. (1983) concluded that grasses tolerate severe grazing in low and high productivity environments through belowground storage of carbon and nutrients. Woody plants are more likely to use growth-limiting, browse-resistant strategies such as chemical defence of leaves, particularly in low nutrient environments. McNaughton et al. (1998) showed that even under intense herbivory from large ungulates, belowground productivity was not inhibited in a Serengeti grassland. In a study of a sedge (Cyperaceae) and a grass (Poaceae) in the Serengeti, McNaughton and Chapin (1985) found that simulated herbivory had greatest effects with high nutrient levels. McLaren (1996) found that simulated moose browsing on naturally browsed balsam fir had a greater effect at more shaded sites in his Michigan study site, and he concluded that both shade and herbivory provide additional stress on the branch growth of trees (Maschinski and Whitham 1989). Some of the inconsistencies in results among studies might be explained by the different effects of browsers and grazers. Browsers are better adapted to feeding on woody seedlings high in chemicals such as monoterpenes and phenols that interfere with rumen microbial activity (Duncan et al.1994). Larger forest dwelling ungulates with relatively slow digestion, and large mouths, bodies and rumens are better adapted to grazing plants high in cellulose such as grasses (Hanley 1997). Other differences among studies might also be explained by a group of unknown variables. 
The present study shows an example of reduced woody seedling growth and survival caused by competition from a browse-tolerant turf community. It appears that these turf communities are induced by intensive deer browsing (Husheer et al. 2003), and that browsing also suppresses seedling establishment and growth. Therefore, deer browsing not only has a direct negative effect on mountain beech seedling growth through stem removal, but also an indirect negative effect by encouraging the production of a growth-reducing turf (Husheer et al. 2003). This study also shows that these effects do not interact with the availability of light and nutrients. Because there is no evidence of species compositional shifts in turf communities following deer exclusion, we conclude that the effects on beech seedling growth from deer-induced turfs cannot be immediately reversed through reductions in deer browsing. It remains unclear at this stage, if any suppression of mountain beech regeneration due to the presence of turf communities can be reversed following reductions in deer abundance over longer periods of time. Further research is required to determine why there is so much variability in results among existing studies on relationships between resource availability, plant competition and herbivory. If a key set of factors responsible for this variation among habitats is identified the ability of ecologists to predict the responses of plant communities to herbivory will be improved tremendously.

\section{Acknowledgements}

We thank the numerous fieldworkers who have helped with data collection and processing, particularly Lotta Risberg, Sofia Lund, Annelies Pronker, Brent Tandy, Anna Lagerström, Kelly Ward, Dan Smale, Adam Robertson, Troy Duncan, Tilly Baker, Andre Koppe, Iciar Alberdi, Daisy Dent, Jenny Hurst, Emma Cardno, Tia Lähteenmäki, Colin Taylor and Steve Deverell. Lotta Risberg diligently analysed hemispherical photographs. Barbara Polly and John Braggins assisted with bryophyte identification. Angela Taylor weighed seedlings and Ian Henderson provided valuable advice on analysis. Comments from Helen Oleary, Angela Moles and anonymous reviewers substantially improved the manuscript, for which we are indebted. The New Zealand Department of Conservation Science and Research Unit supported this paper (investigation 2493).

\section{References}

Atchley W.R., Gaskins C.T. and Anderson D. 1976. Statistical properties of ratios. Syst. Zool. 25: 137-148.

Bazzaz F.A. 1996. Plants in Changing Environments: Linking Physiological, Population, and Community Ecology. Cambridge University Press, New York, NY, USA.

Beever J., Allison K.W. and Child J. 1992. The Mosses of New Zealand. University of Otago Press, Dunedin, New Zealand.

Belsky A.J. 1992. Effects of grazing, competition, disturbance, and fire on species composition and diversity in grassland communities. J. Veget. Sci. 3: 187-200.

Bond W.J., Lee W.G. and Craine J.M. 2004. Plant structural defences against bird browsers: a legacy of New Zealand's extinct moas. Oikos 104: 500-508.

Bonser S.P. and Reader R.J. 1995. Plant competition and herbivory in relation to vegetation biomass. Ecology 76 :: 2176-2183.

Brownsey P.J. and Smith-Dodsworth J.C. 2000. New Zealand Ferns and Allied Plants. David Bateman, Auckland.

Bryant J.P., Chapin F.S. and Klein D.R. 1983. Carbon/nutrient balance of boreal plants in relation to vertebrate herbivory. Oikos 40: 357-368.

Cahill J.F. 1999. Fertilization effects on interactions between above- and below-ground competition in an old field. Ecology 80: $466-480$.

Cahill J.F. 2002. What evidence is necessary in studies which separate root and shoot competition along productivity gradients? J. Ecol. 90: $201-205$.

Cebrián J. and Duarte C.M. 1994. The dependence of herbivory on growth rate in natural plant communities. Funct. Ecol. 8: $518-525$.

Chase J.M., Leibold M.A., Downing A.L. and Shurin J.B. 2000. The effects of productivity, herbivory, and plant species turnover in grassland food webs. Ecology 81: 2485-2497.

Coley P.D. 1983. Herbivory and defensive characteristics of tree species in a lowland tropical forest. Ecol. Monogr. 53: 209233.

Coley P.D., Bryant J.P. and Chapin F.S. 1985. Resource availability and plant anti-herbivore defence. Science 230 : 895-899.

Collins S.L., Knapp A.K., Briggs J.M., Blair J.M. and Steinauer E.M. 1998. Modulation of diversity by grazing and mowing in native tallgrass prairie. Science 280: $745-$ 747.

Coomes D.A. and Grubb P.J. 1998. Responses of juvenile trees to above- and belowground competition in nutrient starved Amazonian rain forest. Ecology 79: 768-782.

Coomes D.A. and Grubb P.J. 2000. Impacts of root competition in forests and woodlands: a theoretical framework and review of experiments. Ecol. Monogr. 70: 171-207.

Coughenour M.B., McNaughton S.J. and Wallace L.L. 1985. Responses of an African tall-grass (Hyparrhenia filipendula 
Stapf.) to defoliation and limitations of water and nitrogen. Oecologia 68: 80-86.

Crawley M.J. 1983. Herbivory: The Dynamics of Animal-Plant Interactions. Blackwell Science, Oxford.

Crawley M.J. 1993. On the consequences of being eaten. Evol. Ecol. 7: 124-125.

Crawley M.J. 1997. Plant-herbivore dynamics. In: Crawley M.J. (ed.), Plant Ecology, Blackwell Science, Oxford, pp. $401-474$

Darwin C. (1859). The Origin of Species. Wordworth Classics of World Literature. Wordworth Edition Limited (1998).

Davidson D.W. 1993. The effects of herbivory and grainivory on terrestrial plant succession. Oikos 68: 23-35.

Di Tommaso A. and Aarssen L.W. 1989. Resource manipulations in natural vegetation: a review. Vegetatio 84: $9-$ 29.

Duncan A.J., Hartley S.E. and Iason G.R. 1994. The effect of monoterpene concentrations in sitka spruce Picea sitchensis on the browsing behaviour of red deer Cervus elaphus. Can. J. Zool. 72: 1715-1720.

Eagle A. 1986. Eagles's Trees and Shrubs of New Zealand. Collins, Auckland.

Edgar E. and Connor H.E. 2000. Flora of New Zealand V. Graminae. Manaaki Whenua Press, Lincoln, New Zealand.

Eriksson A., Eriksson O. and Berglund H. 1995. Species abundance patterns of plants in Swedish semi-natural pastures. Ecography 18: 310-317.

Frazer G.W., Canham C.D. and Lertzman K.P. (1999). Gap Light Analyzer (GLA), Version 2: imaging software to extract canopy structure and gap light transmission indices from true-color fisheye photographs. Simon Fraser University, Canada and Institute of Ecosystem Studies, Millbrook, USA. http://www.rem.sfu.ca/forestry or http://www.ecostudies.org.

Frazer G.W., Fournier R.A., Trofymow J.A. and Hall R.J. 2001. A comparison of digital and film fisheye photography for analysis of forest canopy structure and gap light transmission. Agric. Forest Meteorol. 109: 249-263.

Goldberg D.E. and Barton A.M. 1992. Patterns and consequences of interspecific competition in natural communities: a review of field experiments with plants. Am. Nat. 139: $771-$ 801.

Gough L. and Grace J.B. 1998. Herbivore effects on plant species density at varying productivity levels. Ecology 79: $1586-1594$.

Greenwood R.M. and Atkinson I.A.E. 1977. Evolution of divaricating plants in New Zealand in relation to moa browsing. Proc. N Z Ecol. Soc. 24: 21-33.

Grime J.P. 1979. Plant Strategies and Vegetation Processes. John Wiley and Sons, Chichester.

Grover J.P. 1995. Competition, herbivory and enrichment: nutrient based models for edible and inedible plants. Am. Nat. 145: 746-774.

Hanley T.A. 1997. The nutritional view of understanding and complexity in the problem of diet selection by deer (Cervidae). Oikos 79: 209-218.

Hawkes C.V. and Sullivan J.J. 2001. The impact of herbivory on plants in different resource conditions: a meta-analysis. Ecology 82: 2045-2058.

Hellström K., Huhta A.-P., Rautio P., Tuomi J., Oksanen J. and Laine K. 2003. Use of sheep grazing in the restoration of semi-natural meadows in northern Finland. Appl. Veget. Sci. 6: $45-52$.

Hicks S.L. and Reader R.J. 1995. Compensatory growth of three grasses following simulated grazing in relation to soil nutrient availability. Can. J. Bot. 73: 141-145.

Hilbert D.W., Swift D.M., Detling J.K. and Dyer M.I. 1981. Relative growth rates and the grazing optimization hypothesis. Oecologia 51: 14-18.

Hjältén J., Danell K. and Ericson L. 1993. Effects of simulated herbivory and intraspecific competition on the compensatory ability of birches. Ecology 74: 1136-1142.

Huisman J., Grover J.P., Van der Wal R. and Van Andel J. 1999. Competition for light, plant species replacement, and herbivore abundance along productivity gradients. In: Olff H., Brown V.K. and Drent R.H. (eds), Herbivores: Between Plants and Predators, Blackwell Science, Oxford.

Hulme P.E. 1996. Herbivores and the performance of grassland plants: a comparison of arthropod, mollusc and rodent herbivory. J. Ecol. 84: 43-51.

Husheer S.W. 2003. The impacts of deer on Kaimanawa beech forest vegetation. Massey University, New Zealand PhD Thesis.

Husheer S.W. and Robertson A.W. 2005. High-intensity deer culling increases mountain beech seedling growth in New Zealand. Wildlife Res 32: 273-280.

Husheer S.W., Coomes D.A. and Robertson A.W. 2003. Longterm influences of introduced deer on the composition and structure of New Zealand Nothofagus forests. Forest Ecol. Manage. 181: 99-117.

Kullberg Y. and Welander N.T. 2003. Effects of simulated winter browsing and drought on growth of Quercus robur L. seedlings during establishment. Forest Ecol. Manage. 173: $125-133$.

Leader-Williams N., Smith R.I.L. and Rothery P. 1987. Influence of introduced reindeer on the vegetation of South Georgia: results from a long-term exclusion experiment. J. Appl. Ecol. 24: 801-822.

Lee W.G. and Fenner M. 1989. Mineral nutrient allocation in seeds and shoots of twelve Chinochloa species in relation to soil fertility. J. Ecol. 77: 704-716.

Leibold M.A. 1996. A graphical model of keystone predators in food webs: trophic regulation of abundance, incidence, and diversity patterns in communities. Am. Nat. 147: 784 812.

Louda S.M., Keeler K.H. and Holt R.D. 1990. Herbivore influences on plant performance and competitive interactions. In: Grace J.B. and Tilman D. (eds), Perspectives on Plant Competition, Academic Press, New York, USA, pp. 414-444.

MacEwen W.M. 1987. Ecological Regions and Districts of New Zealand 3rd ed. Department of Conservation, Wellington.

Maschinski J. and Whitham T.G. 1989. The continuum of plant responses to herbivory: the influence of plant association, nutrient availability, and timing. Am. Nat. 134: 1-19.

McCune B. and Cottam G. 1985. The successional status of a southern Wisconsin Oak woods. Ecology 66: 1270-1278.

McLaren B.E. 1996. Plant-specific response to herbivory: simulated browsing of suppressed balsam fir on Isle Royale. Ecology 77: 228-235.

McNaughton S.J. 1983. Compensatory plant growth as a response to herbivory. Oikos 40: 329-336. 
McNaughton S.J. 1984. Grazing lawns: animals in herds, plant form and evolution. Am. Nat. 124: 863-886.

McNaughton S.J., Banyikwa F.F. and McNaughton M.M. 1998. Root biomass and productivity in a grazing ecosystem: the Serengeti. Ecology 79: 587-592.

McNaughton S.J. and Chapin F.S. 1985. Effects of phosphorus nutrition and defoliation on $\mathrm{C}^{4}$ graminoids from the Serengeti plains. Ecology 66: 1617-1629.

Meyer G.A. 2000. Interactive effects of soil fertility and herbivory on Brassica nigra. Oikos 88: 433-441.

Mitchell A.D., Frodin D.G. and Heads M.J. 1997. Reinstatement of Raukaua, a genus of the Araliaceae, centred in New Zealand. N Z J. Bot. 35: 309-315.

Mueller-Dombois D. and Ellenberg H. 1974. Aims and Methods of Vegetation Ecology. John Wiley and Sons, New York, U.S.A.

Nams V.O., Folkard N.F.G. and Smith J.N.M. 1996. Nitrogen fertilization stimulates herbivory by snowshoe hares in the boreal forest. Can. J. Zool. 74: 196-199.

Olff H., Vera F.W.M., Bokdam J., Bakker E.S., Gleichman J.M., de Maeyer K. and Smit R. 1999. Shifting mosaics in grazed woodlands driven by the alteration of plant facilitation and competition. Plant Biol. 1: 127-137.

Pacala S.W. and Crawley M.J. 1992. Herbivores and plant diversity. Am. Nat. 140: 243-260.

Parsons M.J., Douglass P. and Macmillan B.H. 1995. Current Names List for Wild Gymnosperms, Dicotyledons and Monocotyledons (except grasses) in New Zealand. Manaaki Whenua Press, Lincoln, New Zealand.

Posse G., Anchorena J. and Collantes M.B. 2000. Spatial micro-patterns in the steppe of Tierra del Fuego induced by sheep grazing. J. Veget. Sci. 11: 43-50.

Platt K.H., Allen R.B., Coomes D.A. and Wiser S.W. 2004. Mountain beech seedling responses to removal of belowground competition and fertiliser addition. N Z J. Ecol. 28: $289-293$.

Reader R.J. 1992. Herbivory as a confounding factor in an experiment measuring competition among plants. Ecology 73: $373-376$.

Rosenthal J.P. and Kotanen P.M. 1994. Terrestrial plant tolerance to herbivory. Trends Ecol. Evol. 9: 145-148.

Ryser P. 1993. Influences of neighbouring plants on seedling establishment in limestone grassland. J. Veget. Sci. 4: 195202.

Schmid B., Miao S.L. and Bazzaz F.A. 1990. Effects of simulated root herbivory and fertilizer application on growth and biomass allocation in the clonal perennial Solidago canadensis. Oecologia 84: 9-15.

Sokal R.R. and Rohlf F.J. 1995. Biometry. W.H. Freeman, New York, U.S.A.

SPSS. 2000. SYSTAT 10.0. SPSS Inc., Chicago, USA.

Swank S.E. and Oechel W.C. 1991. Interactions among the effects of herbivory, competition, and resource limitation on chaparral herbs. Ecology 72: 104-115.

Taylor J.B., Grace K.L. and Marx B.D. 1997. The effects of herbivory on neighbour interactions along a coastal marsh gradient. Am. J. Bot. 84: 709-715.

Ter Braak C.J.E. and Smilauer P. 1998. CANOCO 4.0. Centre of Biometry, Wageningen, The Netherlands.

Van Auken O.W. and Bush J.K. 1989. Prosopis glandulosa growth: influence of nutrients and simulated grazing of Boutela curtipendula. Ecology 70: 512-516.

Van de Koppel J., Huisman J., Van der Wal R. and Olff H. 1996. Patterns of herbivory along a productivity gradient: an empirical and theoretical investigation. Ecology 77: 736-745.

Van der Wal R., Egas M., Van der Veen A. and Bakker J. 2000. Effects of resource competition and herbivory on plant performance along a natural productivity gradient. J. Ecol. 88: $317-330$.

Virtanen R. 2000. Effects of grazing on above-ground biomass on a mountain snowbed, NW Finland. Oikos 90: $295-300$.

Wandera J.L., Richards J.H. and Mueller R.J. 1992. The relationships between relative growth rate, meristematic potential and compensatory growth of semi-arid land shrubs. Oecologia 90: 391-398.

Whittaker J.B. 1979. Invertebrate grazing, competition and plant dynamics. In: Anderson R.M., Turner B.D. and Taylor L.R. (eds), Population Dynamics, Blackwell Scientific Publications, Oxford, pp. 207-222.

Wilson C.J.N., Ambraseys N.N., Bradley J. and Walker G.P.L. 1993. A new date for the Taupo eruption, New Zealand. Nature 288: 252-253.

Wilson H.D. and Galloway T. 1993. Small-Leaved Shrubs of New Zealand. Manuka Press, Christchurch.

Wilson S.D. and Tilman D. 1991. Components of plant competition on an experimental gradient of nitrogen availability. Ecology 72: 1050-1065.

Wiser S.K., Allen R.B. and Platt K.H. 1997. Mountain beech forest succession after a fire at Mount Thomas Forest, Canterbury, New Zealand. N Z J. Bot. 35: 505-515. 